\title{
Compare Cooling Effect of Different Working Fluid in Thermosyphon
}

\author{
P. Hrabovský ${ }^{1, a}$, P. Nemec $^{1}$ and M. Malcho ${ }^{1}$ \\ ${ }^{1}$ University of Žilina, Faculty of Mechanical Engineering, Department of Power Engeneering, Univerzitna 1, 01026 Žilina, \\ Slovakia
}

\begin{abstract}
This work examines cooling effect of various working fluids types, which are used in thermosyphon at cooling electrical component, it's connected to power supply. Measurement is realized at various heat output, which maximal value is limited with maximal operating value of electrical component.
\end{abstract}

\section{Introduction}

Loop thermosyphon is a special type of the heat pipe consisting of an evaporator and condenser which are joined with transfer tubes. The evaporator is situated below the condenser. Heat pipes are used as heat transfer. Heat conductivity of heat pipe can be higher than heat conductivity of some metal materials (et. copper). After successful demonstration of the ability and reliability of heat transfer in space applications, the loop thermosyphon experienced the attention of the world in 1990 [1]. Loop thermosyphons are used in the space industry for cooling of electrical equipment on spaceship now, are capable of passive cooling of equipment at normal operation conditions [2]. The phenomenon is often used in the design of solar water heaters, particular of small capacities [3]. Volume of wasted heat depend on the specific heat capacity and boiling point working fluid.

\section{Design of loop thermosyphon}

The aim of this work is to compare flat condensers and ribbed tubes condenser as part of the loop thermosyphon. The loop thermosyphon consists of evaporator, condenser and transfer tubes. The evaporator is located in the lower part of the loop thermosyphon. It is made of aluminium block and its measures are 155 x 80 x $30 \mathrm{~mm}$ ( $\mathrm{H} \times \mathrm{W} \times \mathrm{D})$. Inside the evaporator there is a tube system of four vertical holes with the diameter of $5 \mathrm{~mm}$, the distance between them is $15 \mathrm{~mm}$. This tube system is connected with two holes with the diameter of $10 \mathrm{~mm}$, which are located on the sides of the evaporator for input and output of working fluid [4]. On the front side of the evaporator semiconductor device is installed. It is connected to a laboratory power supply (of electric voltage and current) and it produces heat. The evaporator and semiconductor device are stuck with heat conductive paste to increase the heat transfer. The temperature of the semiconductor device is controlled by a thermometer to prevent it from the heat failure.
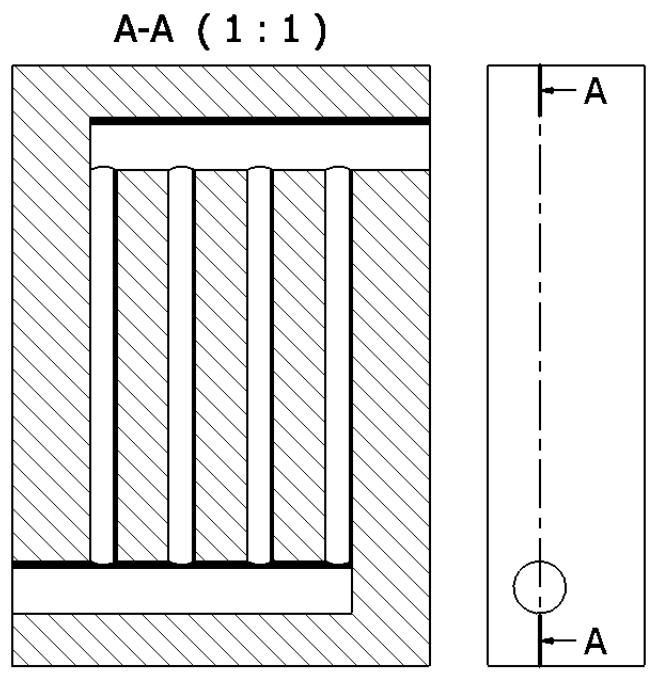

Figure 1 Cross-section of evaporator.

\footnotetext{
a peter.hrabovsky@fstroj.uniza.sk
} 


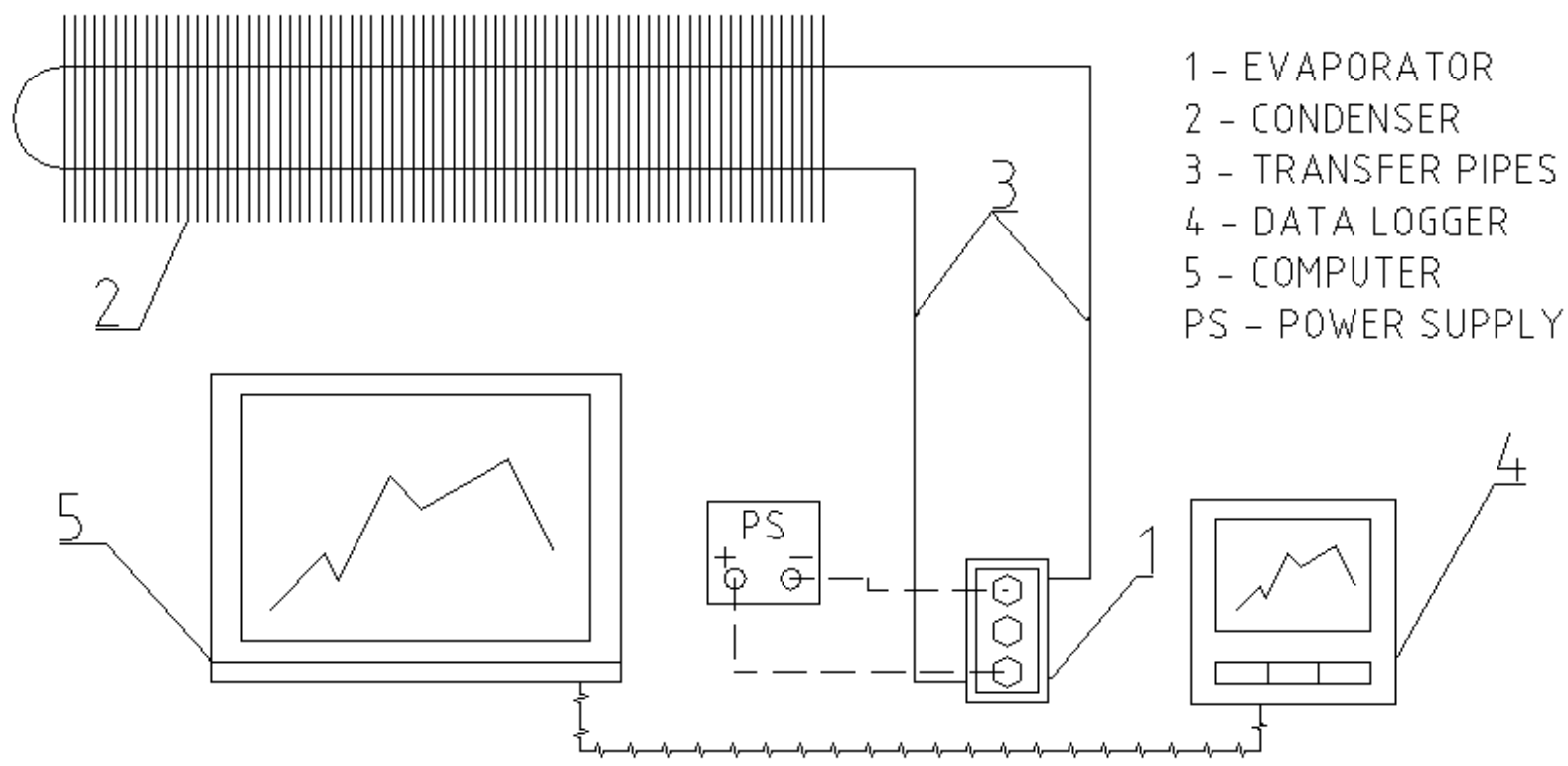

Figure 2 Diagram of devide.

Transfer tubes consist of copper pipes, copper and brass fittings and fastenings which are connected to evaporator and condenser with soft solders and soldering technology. Outside diameter of copper tubes is $10 \mathrm{~mm}$, wall thickness $1 \mathrm{~mm}$. Total length of the transfer tubes, including fittings and fastenings, is $1 \mathrm{~m}$. Capacity of tubes is $50.3 \mathrm{ml}$. The condenser is located in higher part of the loop thermosyphon. It consist of copper tubes and steel ribs. The ribs are pressed on the tubes. Ribs spacing is $3 \mathrm{~mm}$ and rib dimension are $100 \times 30 \times 0.5 \mathrm{~mm}$ ( $\mathrm{H} \times \mathrm{W} \times \mathrm{D})$. Outdoor diameter of copper tube is $15 \mathrm{~mm}$. The condenser is connected via copper tubes to evaporator.

\section{Working substance}

The working substance used in loop thermosyphon is chosen from the range of liquids depending on their operating temperature. According to operating temperature, the working substances are sorted into four classes: cryogenic $(4-200 \mathrm{~K})$, low $(200-550)$, medium $(500-750 \mathrm{~K})$, high $(750 \mathrm{~K}$ and more) operating temperature. The loop thermosyphons are mostly used in applications requiring lower operating temperature. A very important fact at choosing the type of working substance is the compatibility between the working substance and the material of device. It is necessary to avoid every chemical reaction between the working substance and the material of device, because it creates a non-condensable gas in the system [5]. This reaction considerably reduces effect of the loop thermosyphon. We used fluorinert FC-72, acetone, ethyl alcohol and distilled water as a working substance in our investigation. Our choice was based on dielectric properties of this liquid in order not to cause short circuits and damage to the electrical equipment.

\subsection{Ethyl alcohol}

Pure and denatured alcohol are used in the production of flavour extracts and concentrates for soft drinks and food products, distilled white vinegar, personal care products such as mouthwash, hair sprays, astringents, colognes and perfumes, and a wide range of chemical and pharmaceutical intermediates.

Table 1. Properties of ethylalkohol

\begin{tabular}{|l|l|}
\hline Properties & $\begin{array}{l}\text { Ethyl } \\
\text { alcohol }\end{array}$ \\
\hline Chemical formula & $\mathrm{C}_{2} \mathrm{H}_{5} \mathrm{OH}$ \\
\hline Molecular Weight & 66 \\
\hline $\begin{array}{l}\text { Heating Value }(\mathrm{Btu} / \mathrm{lb}) \\
\text { High Value } \\
\text { Low Value }\end{array}$ & 12.780 \\
\hline Latent Heat of Vaporization $(\mathrm{Btu} / \mathrm{lb})$ & 11.550 \\
\hline Specific Gravity $\left(60^{\circ} \mathrm{F}\right)$ & 361 \\
\hline Stoichiometric Ratio & 0.794 \\
\hline Boiling Temperature $\left({ }^{\circ} \mathrm{F}\right)$ & $9: 1$ \\
\hline Octane Number $($ Research) & 173.3 \\
\hline $\begin{array}{l}\text { Energy of Stoichiometric Mixture } \\
\left(\text { Btu / } \mathrm{ft}^{3}\right)\end{array}$ & 106 \\
\hline & 94.7 \\
\hline
\end{tabular}

\subsection{Fluorinert FC-72}

Fluorinert FC-72 is a clear, colourless, fully-fluorinated liquid. It is thermally and chemically stable, compatible with sensitive materials, non-flammable, practically nontoxic and leaves essentially no residue upon evaporation. This unique combination of properties makes Fluorinert FC-72 ideal for many electronics applications, including quality and reliability testing. 
Table 2. Properties of Fluorinert FC-72

\begin{tabular}{|c|c|}
\hline Properties & FC-72 \\
\hline Appearance & Clear, colourless \\
\hline Average Molecular Weight & 338 \\
\hline Boiling Point (1 atm) & $60^{\circ} \mathrm{C}$ \\
\hline Pour Point & $-90^{\circ} \mathrm{C}$ \\
\hline Estimated Critical Temperature & $449 \mathrm{~K}$ \\
\hline Estimated Critical Pressure & $\begin{array}{l}1.83 \times 10^{6} \\
\text { pascals }\end{array}$ \\
\hline Vapour Pressure & $\begin{array}{l}30.9 \times 10^{3} \\
\text { pascals }\end{array}$ \\
\hline $\begin{array}{l}\text { Latent Heat of Vaporization (at } \\
\text { normal boiling point) }\end{array}$ & $88 \mathrm{~J} / \mathrm{g}$ \\
\hline Liquid Density & $1680 \mathrm{~kg} \mathrm{~m}^{-3}$ \\
\hline Kinematic Viscosity & 0.38 centistokes \\
\hline Absolute Viscosity & 0.64 centipoise \\
\hline Liquid Specific Heat & $1100 \mathrm{~J} \mathrm{~kg}^{-1} \mathrm{C}^{-1}$ \\
\hline Liquid Thermal Conductivity & $0.057 \mathrm{~W} \cdot \mathrm{m}^{-1} \cdot \mathrm{C}^{-1}$ \\
\hline Coefficient of Expansion & $0.00156^{\circ} \mathrm{C}^{-1}$ \\
\hline Surface Tension & 10 dynes $/ \mathrm{cm}$ \\
\hline Refractive Index & 1.251 \\
\hline Water Solubility & 10 ppmw \\
\hline Solubility in Water & $<5 \mathrm{ppmw}$ \\
\hline Ozone Depletion Potential & 0 \\
\hline Dielectric Strength & $38 \mathrm{kV}, 0.1$ "gap \\
\hline Dielectric Constant & 1.75 \\
\hline Electrical Resistivity & $\begin{array}{l}1.0 \times 10^{15} \mathrm{ohm} \\
\mathrm{cm}\end{array}$ \\
\hline
\end{tabular}

\subsection{Distilled water}

Distilled water is a colourless, limpid liquid, without odours or taste, and of neutral reaction. On evaporating one liter of distilled water no fixed residue should remain. The transparency or colour of distilled water should not be affected by hydro sulphuric acid or sulphide of ammonium (absence of metals), by test solutions of chloride of barium (sulphate), nitrate of silver (chloride), oxalate of ammonium (calcium), or mercuric chloride, with or without the subsequent addition of carbonate of potassium (ammonia and ammonium salts). On heating $100 \mathrm{com}$. of distilled water acidulated with $10 \mathrm{ccm}$. Of diluted sulphuric acid to boiling, add enough of a dilute solution of permanganate of potassium (1 in 1000) to impart to the liquid a decided rose-red tint; this tint should not be entirely destroyed by boiling for five minutes (absence of organic or other oxidizable matters).
Table 3. Properties of distilled water

\begin{tabular}{|l|l|}
\hline Properties & Distilled Water \\
\hline Chemical formula & $\mathrm{H}_{2} \mathrm{O}$ \\
\hline Molecular Weight & 18 \\
\hline Appearance & $\begin{array}{l}\text { White solid or almost colourless, } \\
\text { transparent with } \\
\text { a slight hint of blue, crystalline solid } \\
\text { or liquid }\end{array}$ \\
\hline Density (1 atm) & 999.972 \\
\hline Melting Point & $0^{\circ} \mathrm{C}\left(32^{\circ} \mathrm{F}, 273.15 \mathrm{~K}\right)$ \\
\hline Boiling Point & $99.98^{\circ} \mathrm{C}\left(211.96^{\circ} \mathrm{F}, 373.13 \mathrm{~K}\right)$ \\
\hline $\begin{array}{l}\text { Thermal } \\
\text { Conductivity }\end{array}$ & $0.58 \mathrm{~W} / \mathrm{m} \mathrm{K}^{-1}$ \\
\hline Refractive index & 1.3325 \\
\hline Viscosity & $1 \mathrm{cP}$ \\
\hline $\begin{array}{l}\text { Specific heat } \\
\text { capacity }\end{array}$ & $75.375 \pm 0.05 \mathrm{~J} / \mathrm{mol} \mathrm{K}^{-1}$ \\
\hline
\end{tabular}

\subsection{Acetone}

Acetone (systematically named propanone) is the organic compound with the formula $\left(\mathrm{CH}_{3}\right)_{2} \mathrm{CO}$. It is a colourless, volatile, flammable liquid, and is the simplest ketone.

Table 4. Properties of Acetone

\begin{tabular}{|c|c|}
\hline Properties & Acetone \\
\hline Chemical Formula & $\mathrm{CH}_{3} \mathrm{CO} \mathrm{CH}_{3}$ \\
\hline Appearance & Clear water white liquid \\
\hline Physical State & Liquid \\
\hline Molecular Weight & 58.08 \\
\hline Density at $20^{\circ} \mathrm{C}, 68^{\circ} \mathrm{F}$ & $6.63 \mathrm{lb} /$ US gal \\
\hline Dielectric Constant $25^{\circ} \mathrm{C}$ & 21.45 \\
\hline $\begin{array}{l}\text { Specific Gravity } \\
\left(25^{\circ} \mathrm{C} / 25^{\circ} \mathrm{F}\right)\end{array}$ & Not over 0.7880 \\
\hline Vapour Density $($ Air= $=1.0)$ & 2 \\
\hline $\begin{array}{l}\text { Vapour Pressure at } 20^{\circ} \mathrm{C}, \\
68^{\circ} \mathrm{F}\end{array}$ & $181.7 \mathrm{mmHg}(3.51 \mathrm{psi})$ \\
\hline Viscosity at $15^{\circ} \mathrm{C}, 59^{\circ} \mathrm{F}$ & $0.3371 \mathrm{cP}$ \\
\hline $\begin{array}{l}\text { Water Solubility } \\
\text { (miscibility) }\end{array}$ & $\begin{array}{l}\text { Soluble in all proportions } \\
\text { in water }\end{array}$ \\
\hline Threshold Limit (toxicity) & $1000 \mathrm{ppm}$ \\
\hline $\begin{array}{l}\text { Explosive Limits (by } \\
\text { volume air) }\end{array}$ & $\begin{array}{l}\text { Lower: } 2.6 \% \text {, Upper: } \\
12.8 \%\end{array}$ \\
\hline Auto ignition Temperature & $560^{\circ} \mathrm{C}\left(1040^{\circ} \mathrm{F}\right)$ \\
\hline Boiling Point $(760 \mathrm{~mm})$ & $56.1^{\circ} \mathrm{C}\left(133^{\circ} \mathrm{F}\right)$ \\
\hline $\begin{array}{l}\text { Melting Point (freezing } \\
\text { point) }\end{array}$ & $-93.9^{\circ} \mathrm{C}\left(-137^{\circ} \mathrm{F}\right)$ \\
\hline Colour & Colourless \\
\hline
\end{tabular}

\section{Experiment and results}

At the beginning of the experiment we have to arrange that the loop thermosyphon contains only pure working substance without air.The purity is the first step to achieve the successful results. Then the data logger is turned on to follow and record heat load and temperature of evaporator, condenser. The power source is set at $80 \mathrm{~W}$ of the heat load. The liquid is heated until 
evaporator temperature become stable. Then the heat load is gradually increased by $20 \mathrm{~W}$. The process of heating continues until evaporator's temperature reaches $100^{\circ} \mathrm{C}$. The percentage of working substance is $50 \%$.

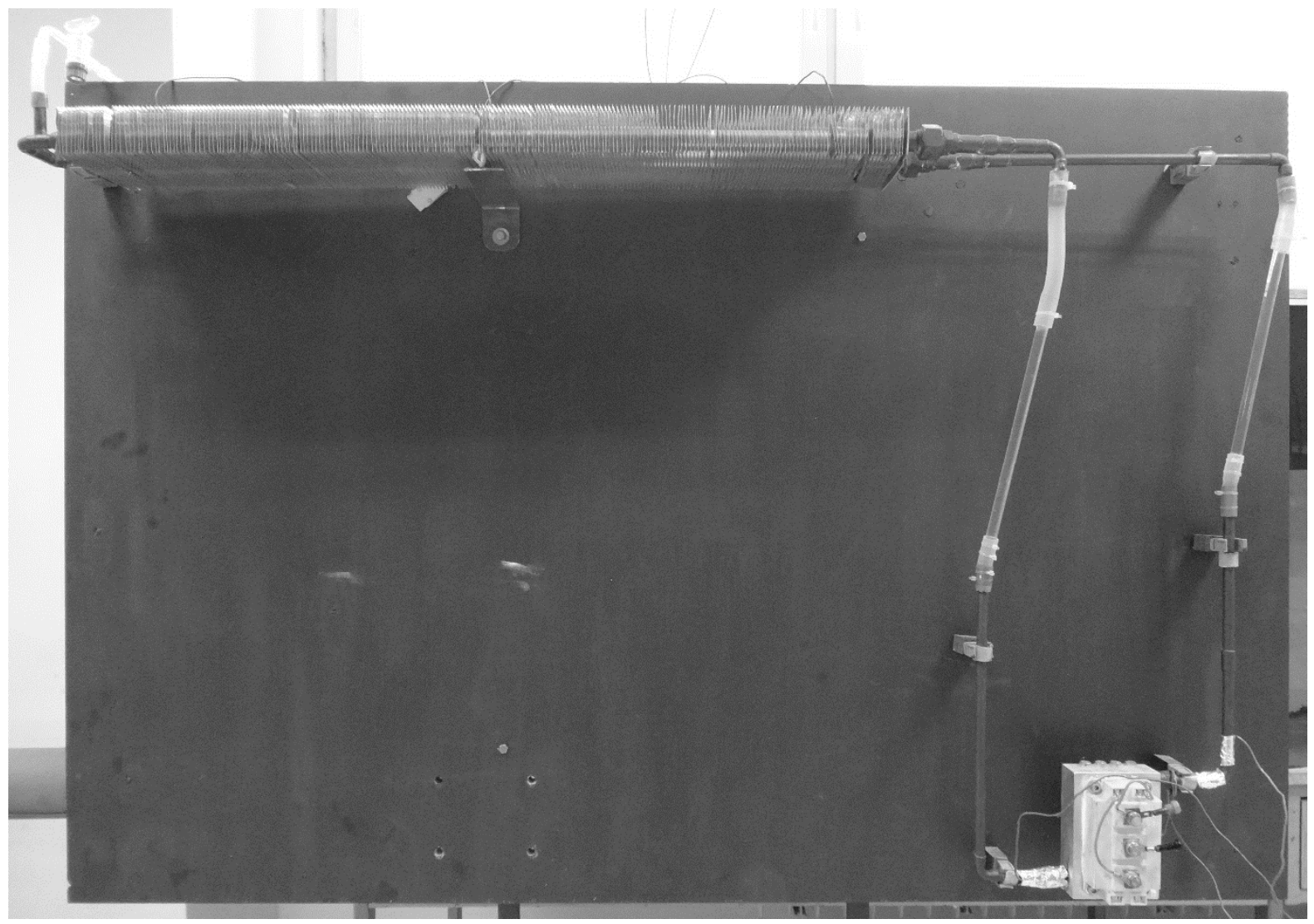

Figure 3 Loop termosyphon at experiment

The measurement data of evaporator's temperature are showing in table 5. The values are for all of the working substances at corresponded heat load.

Table 5. Value of evaporator's temperature

\begin{tabular}{|c|c|c|c|c|}
\hline $\begin{array}{c}\text { Thernal } \\
\text { load }\end{array}$ & $\begin{array}{c}\text { Fluorinert } \\
\text { FC-72 }\end{array}$ & $\begin{array}{c}\text { Distilled } \\
\text { Water }\end{array}$ & Acetone & $\begin{array}{c}\text { Ethyl } \\
\text { alcohol }\end{array}$ \\
\hline 80 & 50.64 & 74.95 & 49.28 & 57.03 \\
\hline 100 & 54.60 & 78.60 & 58.31 & 62.66 \\
\hline 120 & 58.10 & 79.97 & 60.85 & 67.73 \\
\hline 140 & 61.04 & 81.43 & 64.33 & 72.47 \\
\hline 160 & 61.70 & 82.64 & 67.76 & 75.92 \\
\hline 180 & 65.32 & 83.78 & 70.07 & 79.56 \\
\hline 200 & 68.42 & 84.84 & 70.73 & 83.25 \\
\hline 220 & 72.13 & 87.44 & 71.52 & 85.65 \\
\hline 240 & 75.04 & 89.32 & 74.57 & 88.26 \\
\hline 260 & 78.39 & 90.96 & 75.76 & 90.46 \\
\hline 280 & 81.12 & 92.83 & 74.73 & 91.62 \\
\hline 300 & 84.54 & 94.33 & 77.74 & 93.01 \\
\hline 320 & 85.50 & 95.75 & 80.53 & 94.00 \\
\hline
\end{tabular}

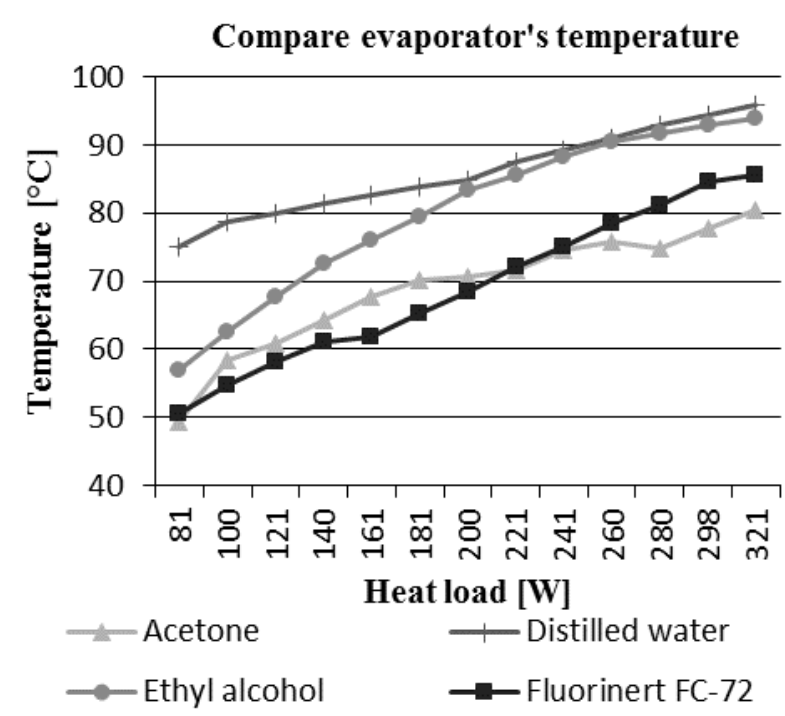

Figure 4. Compare temperatures of evaporator

In the figure 4 is shown depend temperature of heat load.

We can see, that acetone and fluorine achieve the best results of cooling effects as ethyl alcohol and distilled water. 


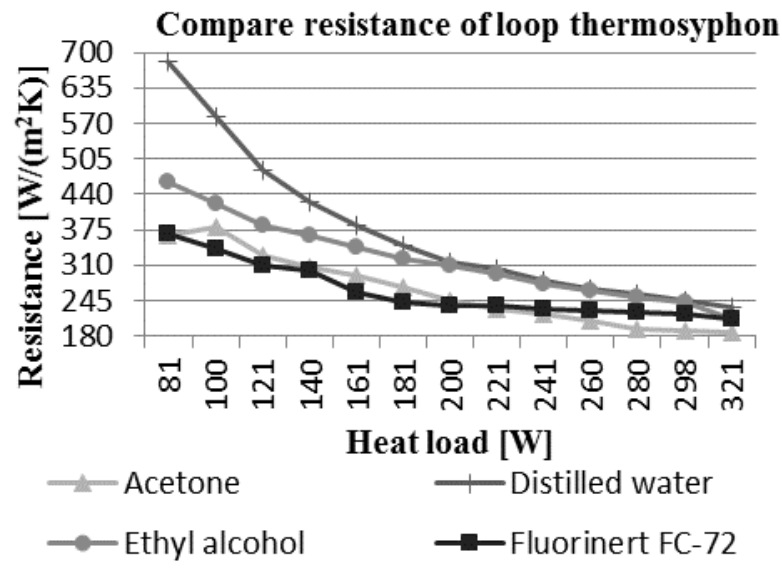

Figure 5. Compare thermal resistance of loop thermosyphon

In the figure 5 is shown depend thermal resistance of heat load. We can see, that with high temperature, which depend on high heat load, is the thermal resistance lower. Acetone achieves the best results of cooling effects as ethyl alcohol distilled water and fluorinert FC-72.

\section{Conclusion}

From this experiment is a consequence, that cooling effect depend not only on construction of device, but on working substance too. We don't known the working substance for ever applications of heat pipe. The used working fluid was comparing for the some experiment. The best cooling effect achieves acetone. Acetone achieve the lowest value of thermal resistance, which is the best for heat transfer to ambient. The next best property is cooling effect of the fluid. Acetone wasted the most capacity of heat from electric element mounted on evaporator. The worst cooling effect achieve distilled water. The cooling effect depend on boiling point and specific heat capacity.

\section{Acknowlegdment}

This article was elaborated within the solution of project APVV 0577-10.

\section{References}

1. M.K. Cheung, T. Hoang, J. Ku, T. Kaya, Proceedings of the 28th International Conference on Environmental Systems. Society of Automotive Engineers, (1988).

2. T. Kaya, J. Ku, T. Hoang, M.K. Cheung, Space Technology and Applications International Forum, (1999).

3. A. Faghri, Washington DC. Taylor \& Francis, (1995).

4. T. Greššák, A. Kapjor, J. Hužvár, EPJ Web of Conferences 45, 01036 (2013)

5. R. Lenhard, K. Kaduchova, Š. Papučík, J. Jandačka, EPJ Web of Conferences 67, 02067 (2014) 